\title{
Testicular dysfunction induced by aluminum oxide nanoparticle administration in albino rats and the possible protective role of the pumpkin seed oil
}

Hamida Hamdi ${ }^{1,2}$ (D)

\begin{abstract}
Background: Even though the widespread of nanoalumina and their benefits in all fields, its potential impacts on male reproductive system have limited information.

Objective: The present study was conducted to investigate the testicular dysfunction of nanoalumina and the protective role of pumpkin seed oil (PSO) against potential adverse impacts induced by alumina nanoparticles $\left(\mathrm{Al}_{2} \mathrm{O}_{3}-\mathrm{NPs}\right)$ in male rat.
\end{abstract}

Methodology: $\mathrm{Al}_{2} \mathrm{O}_{3}-\mathrm{NPs}$ were administered to the rat orally at a dose of $70 \mathrm{mg} / \mathrm{kg}$ body weight once a day for 28 successive days, while pumpkin seed oil was administered to the rat orally at $4 \mathrm{~mL} / \mathrm{kg} b \mathrm{w}$ before administration of $\mathrm{Al}_{2} \mathrm{O}_{3}-\mathrm{NPs}$, once a day for 28 successive days. After the administration period, sperm concentration, motility, morphology, and DNA damage, as biomarkers of reproductive toxic effects, were evaluated using sperm analysis and comet assays, and histopathological examination of testis was performed. In addition, level of the serum testosterone hormones were estimated, and the levels of oxidative stress biomarkers that take part in the reproductive pathologies such as catalase, glutathione, and malondialdehyde were estimated.

Results: The present results revealed that $\mathrm{Al}_{2} \mathrm{O}_{3}-\mathrm{NPs}$ induced DNA damage in testicular cells, marked histopathological alterations, and caused a significant elevation in MDA in testicular tissue. There was a significant decline in GSH and CAT activities. Furthermore, there was a significant decline in serum testosterone level in the testicular tissue of $\mathrm{Al}_{2} \mathrm{O}_{3}-\mathrm{NP}$-administered rats. In contrast, pumpkin seed oil co-administration alleviated DNA damage and improved the histopathological alterations in the testicular tissues. Moreover, pumpkin seed oil coadministration significantly reduced MDA and improved the antioxidant defenses in testicular tissue.

Conclusion: The current study concluded that $\mathrm{Al}_{2} \mathrm{O}_{3}-\mathrm{NPs}$ caused testicular dysfunction by generating oxidative injury. Otherwise, PSO co-administration successfully attenuated the adverse impacts of $\mathrm{Al}_{2} \mathrm{O}_{3}-\mathrm{NPs}$ via suppression of oxidative stress and apoptosis as well as enhancement of the antioxidant defense system.

Keywords: $\mathrm{Al}_{2} \mathrm{O}_{3}$ nanoparticles, Pumpkin seed oil, Lipid peroxidation, Testicular dysfunction

Correspondence: Hamida@sci.cu.edu.eg

${ }^{1}$ Zoology Department, Faculty of Science, Cairo University, Giza, Egypt

${ }^{2}$ Biology Department, Faculty of Science, Taif University, Taif, Saudi Arabia

(c) The Author(s). 2020 Open Access This article is licensed under a Creative Commons Attribution 4.0 International License, which permits use, sharing, adaptation, distribution and reproduction in any medium or format, as long as you give appropriate credit to the original author(s) and the source, provide a link to the Creative Commons licence, and indicate if changes were made. The images or other third party material in this article are included in the article's Creative Commons licence, unless indicated otherwise in a credit line to the material. If material is not included in the article's Creative Commons licence and your intended use is not permitted by statutory regulation or exceeds the permitted use, you will need to obtain permission directly from the copyright holder. To view a copy of this licence, visit http://creativecommons.org/licenses/by/4.0/. 


\section{Introduction}

Alumina nanoparticles $\left(\mathrm{Al}_{2} \mathrm{O}_{3}-\mathrm{NPs}\right)$ are among the most widely used nanoparticle owing to their distinct physical, thermal, chemical, and biological properties (Arul Prakash, Dushendra Babu, Lavanya, Vidhya, \& Devasena, 2011; Shirai, Watanabe, Fuji, \& Takahashi, 2009). $\mathrm{Al}_{2} \mathrm{O}_{3}$ NPs are extensively used in many fields of every-day life, including the modification of polymers, functionalization of textiles, aerospace, electronics, pharmaceutical and cosmetics (Bartsch, Saruhan, Schmücker, \& Schneider, 1999; Feng et al., 2015; Zhang et al., 2007), heat transfer fluids, treatment of wastewater, biosensors (Tarlani, Isari, Khazraei, \& Eslami Moghadam, 2017), biofiltration, drug delivery (Borbane, Pande, Vibhute, Kendre, \& Dange, 2015), and antigen delivery for immunization purposes (Beyzay, Zavaran Hosseini, \& Soudi, 2017; Frey, Neutra, \& Robey, 1997). This excessive utilization of $\mathrm{Al}_{2} \mathrm{O}_{3}$-NPs makes it widely distributed in our environment. Aluminum oxide nanoparticles may possibly enter the food chain and be responsible for toxicity in animals (Rastogi et al., 2017). NPs have greater toxicity than the same conventional sized particles; hence, their potential adverse effects on the health of humans and wildlife have great concerns (Qin et al., 2017; Serra et al., 2019; Tang et al., 2015).

Several studies have reported that $\mathrm{Al}_{2} \mathrm{O}_{3}$-NPs can cross biological barriers and deposit in different body organs and tissues; however, their accumulation at body sites can lead to adverse effects, such as genotoxicity (Balasubramanyam et al., 2009), inflammatory response (Oesterling et al., 2008), carcinogenicity (Dey et al., 2008), cytotoxicity, ROS generation and mitochondrial dysfunction (Chen, Yokel, Hennig, \& Toborek, 2008), neurotoxicity (Chen et al., 2008; Li et al., 2009; Prabhakar et al., 2012; Shrivastava, Raza, Yadav, Kushwaha, \& Flora, 2014; Zhang et al., 2011), and hepato- and nephrotoxicity (Morsy, Abou El-Ala, \& Ali, 2016a, 2016b, 2016c; Shrivastava et al., 2014; Yousef, Mutar, \& Kamel, 2019). Therefore, the potential risks to reproductive health should be investigated, especially in those who are occupationally exposed to $\mathrm{Al}_{2} \mathrm{O}_{3}$-NPs.

Pumpkin seed oil has been widely used not only as edible oil but also as a nutraceutical. PSO is rich in various antioxidant vitamins as $\alpha$ - and $\gamma$-tocopherol, $\beta$ carotene, and vitamin E (Stevenson et al., 2007). Ninety-eight percent of pumpkin seed oil constituents are fatty acids (mainly linoleic acid, oleic acid, palmitic acid, and stearic acid). In addition, PSO contains also phenolic compounds such as vanillic acid, tyrosol, and vanillin and high levels of selenium and lutein (Andjelkov, Camp, Trawka, \& Verhe, 2010). Furthermore, it contains squalene which is a carbon organic compound which has several commercial uses (Nyam, Tan, Lai, Long, \& Che Man, 2009). In addition, it has been shown to contain high levels of phytosterols and proteins (Ryan, Galvin, O'Connor, Maguire, \& O'Brien, 2007). Pumpkin seed oil has many benefits to human health, due to the presence of all these constituents. Nowadays, it is used in treatment of several diseases as diabetes (Caili, Huan, \& Quanhong, 2006), hypertension, hypercholesterolemia (Al-Zuhair, Abd el-Fattah, \& Abd el Latif, 1997), symptomatic micturition disorders (Fruhwirth \& Hermetter, 2007), and arthritis (Fahim, Abd-el Fattah, Agha, \& Gad, 1995). Pumpkin has anti-mutagenic activities as reported by Elfiky, Elelaimy, Hassan, Ibrahim, and Elsayad (2012).

The toxicological impacts of $\mathrm{Al}_{2} \mathrm{O}_{3}$-NPs on male reproductive system have limited information. Therefore, it is important to assess the possible testicular toxicity induced by $\mathrm{Al}_{2} \mathrm{O}_{3}$-NPs administration and the possible protective role of pumpkin seed oil in prevention and/or reduction of toxicity associated with oxidative stress induced by alumina nanoparticle.

\section{Materials and methods Animals}

Twenty adult male Wister rats (Rattus norvegicus; 7-9 weeks old; $180-200 \mathrm{~g}$ body weight) were purchased from the animal house of the Faculty of Veterinary Medicine, Cairo University, Egypt. Animals were placed in the laboratory for a week under the laboratory conditions. The current study is related to the protocol that was approved by the Institutional Animal Care and Use Committee (CU-IACUC) of Cairo University (No. CU/I/F/ 61/19).This study was carried out in accordance with the Guide for the Care and Use of Laboratory Animals 8th Edition 2011.

\section{Materials}

Nanopowder, white, solid $\mathrm{Al}_{2} \mathrm{O}_{3}$-NPs $(\leq 50 \mathrm{~nm})$ were obtained from Sigma-Aldrich (St. Louis, MO, USA, product number 544833). Characterization of aluminum oxide nanoparticles was characterized using Transmission Electron Microscope (HR-TEM, FEL, Tecnia G20); $\mathrm{X}$-ray diffraction (XRD, PanAnalytical, $\mathrm{X}$ pert Pro) was done in my previous work (not published) which confirmed the very thin particles of Al2O3-NPs (nanopowder, $<50 \mathrm{~nm}$ ).

Pumpkin seed oil (PSO), 100\% natural cold pressed pumpkin seed oil, was obtained from Imtenan Health Shop, Egypt.

Mouse Negative Control Serum (932B) was obtained from Sigma-Aldrich.

\section{Experiment design}

Seventy milligrams per kilograms body weight of $\mathrm{Al}_{2} \mathrm{O}_{3}$ NPs was suspended in 1-ml distilled water (aqueous suspension) according to Yousef et al. (2019); the suspensions were ultrasonicated before they were orally 
administered to rats to avoid aggregation and provide an optimum size distribution for dispersed particles. Rats were randomly designed into four groups that had five rats each group. Doses were administered once daily via gastric tube for 28 successive days. Group 1: Control group, untreated rats. Group 2: Pumpkin Seed Oil group, rats were administered with $4 \mathrm{ml} / \mathrm{kg}$ oil according to Sayed (2014). Group 3: nanoalumina group. Group 4: combined group-rats were co-administered with pumpkin seed oil and $\mathrm{Al}_{2} \mathrm{O}_{3}$-NPs aqueous suspension in the same doses in 2nd and 3rd groups. Rats were sacrificed under anesthesia using $50 \mathrm{mg} / \mathrm{kg}$ of sodium pentobarbital. Blood samples were collected for hormonal analysis (testosterone) from the right ventricle of the rats by syringe, and the testicular and epididymal tissues were removed for further assays.

\section{Sperm quality analysis}

Concentration, motility, and viability of sperm are the three parameters used to determine sperm quality. In a Petri dish containing $2 \mathrm{ml}$ phosphate-buffered saline (PBS) at $37^{\circ} \mathrm{C}$, the cauda epididymis was removed and cut into small portions to prepare sperm suspension. The method of hemocytometer was used to analyze concentration and motility of sperm (WHO, 1999). One drop of sperm suspensions was mixed with two drops of $1 \%$ eosin $\mathrm{Y}$ (to determine the viability of the sperm); a total of 1000 sperms were counted to determine the proportion of malformed sperm.

\section{Comet assay}

The alkaline comet assay was carried out according to the method of Nandhakumar et al. (2011). It was performed using testicular tissue of male rats from all the experimental groups. The fluorescent microscope (Carl Zeiss Axioplan with epifluorescence using filter 15 BP546/12, FT580, and LP590) was used to examine the slides. For each sample, the extent of DNA migration was determined by capture of simultaneous image and scoring of 50 cells at magnification $\times 400$ using the Comet 5 image analysis software developed by Kinetic Imaging, Ltd. (Liverpool, UK). By using a closed-circuit digital (CCD) camera, the comet images were captured.

\section{Serum testosterone assay}

By using commercial ELISA kits according to Tietz (1995), serological testosterone hormone was estimated.

\section{Estimation of the markers of oxidative stress and antioxidants}

Tissue homogenate preparation

Testicular tissues of all groups were removed, washed in $0.9 \%$ saline, and then dried on filter paper. One hundred milligrams of tissue was homogenized in $1 \mathrm{ml}$ of PBS and stored at $-20{ }^{\circ} \mathrm{C}$ overnight. The homogenates were centrifuged at $300 \mathrm{rpm}$ for $15 \mathrm{~min}$. Supernatants were used to evaluate malondialdehyde (MDA) according to Ohkawa, Ohishi, and Yagi (1979); glutathione (GSH) according to Beutler, Duron, and Kelly (1963); and catalase (CAT) according to the method of Aebi (1984).

\section{Histopathological assay}

Testicular tissues were fixed in 10\% neutral formalin for $72 \mathrm{~h}$. Testicular tissues were dehydrated in alcohol, cleared in Xylene, and embedded in paraffin wax. Three to $5-\mu \mathrm{m}$ sections were cut by microtome. Hematoxylin and Eosin were used to stain the sections (Bancroft \& Gamble 2008). By using light microscope at magnification $\times 400$, the histological changes were investigated.

\section{Immunohistochemistry for caspase-3}

Immunohistochemical staining of anti-caspase-3 antibodies was performed with streptavidin-biotin (Duan et al., 2003). The sections of 3-5 $\mu \mathrm{m}$ thick were incubated with fresh $0.3 \%$ hydrogen peroxide in methanol for $30 \mathrm{~min}$ at room temperature. The specimens were then incubated with anti-caspase- 3 antibodies as the primer antibody at a 1:100 dilution. After the incubation, the reaction product was visualized with (freshly prepared) diaminobenzidine solution by incubating for 60 min. Finally, sections were counterstained with Mayer's hematoxylin, mounted with mounting medium, and examined with the Olympus $\mathrm{BH} 2$ photo-light microscope (Olympus America Inc., Center Valley, PA, USA). Negative controls were prepared by substituting normal mouse serum for each primary antibody.

\section{Statistical analysis}

Data were represented as mean \pm standard error (SE). Statistical analysis of data was performed using GraphPad Prism 5. Data were analyzed for statistical significance by the one-way analysis of variance, followed by the Tukey's multiple comparison test. The data at $p<$ 0.05 was considered significant.

\section{Results}

\section{Sperm quality analysis}

Table 1 presented the parameters of epididymal spermatozoa of $\mathrm{Al}_{2} \mathrm{O}_{3}$-NPs and/or PSO groups. PSO group did not differ significantly from the control in sperm motility, sperm viability, and abnormal sperm rates. Concentration, motility, and viability of spermatozoa were significantly low in $\mathrm{Al}_{2} \mathrm{O}_{3}$-NP-administrated group compared to the control group. Significant elevation in abnormalities was in the $\mathrm{Al}_{2} \mathrm{O}_{3}$ - $\mathrm{NP}$-administrated group compared to the control group as seen in Table 1 and Fig. 1. Co-administration of PSO significantly alleviated the decrease in concentration, motility, and viability of 
Table 1 Effect of pumpkin seed oil on the percentage of sperm parameters in rat administrated with $\mathrm{Al}_{2} \mathrm{O}_{3}-\mathrm{NPs}$

\begin{tabular}{lllll}
\hline Parameter & Experimental groups & & & \\
\cline { 2 - 5 } & Control & PSO & $\mathrm{Al}_{2} \mathrm{O}_{3}-\mathrm{NPs}$ & $40.13 \pm 0.2394^{\mathrm{a}}$ \\
\hline Sperm concentration $\left(\times 10^{6} \mathrm{ml}^{-1}\right)$ & $79.05 \pm 0.3069$ & $80.85 \pm 0.3617$ & $56.8 \pm 2.478^{\mathrm{a}}$ & $59.4 \pm 0.3109^{\mathrm{b}}$ \\
Sperm motility (\%) & $85.38 \pm 0.4479$ & $86.13 \pm 0.225$ & $59.63 \pm 0.2394^{\mathrm{a}}$ & $70.05 \pm 0.3571^{\mathrm{b}}$ \\
Sperm viability (\%) & $84.18 \pm 0.4131$ & $85.85 \pm 0.3524$ & $21.5 \pm 0.6455^{\mathrm{a}}$ & $69.98 \pm 0.225^{\mathrm{b}}$ \\
Sperm abnormal forms(\%) & $6 \pm 0.4082$ & $5.5 \pm 0.2887$ & $12.25 \pm 0.25^{\mathrm{b}}$ \\
\hline
\end{tabular}

${ }^{a}$ Refers to a significant change from the control rat

${ }^{\mathrm{b}}$ Refers to a significant change from the Al2O3-NP-administrated rat

spermatozoa and significantly lowered the percentage of abnormal spermatozoa compared to $\mathrm{Al}_{2} \mathrm{O}_{3}$-NP-administrated group. PSO had a remarkably protective role against DNA damage caused by $\mathrm{Al}_{2} \mathrm{O}_{3}$-NPs.

\section{Comet assay}

Figure 2 represented the comet cells in all groups. Administration of $\mathrm{Al}_{2} \mathrm{O}_{3}$-NPs for 28 days for male rats revealed an elevated DNA amount in the comet tail in testicular cells. Significant increment $(p<.05)$ in all comet parameters (\% DNA damage, tail length, and tail moment) in testicular cells of $\mathrm{Al}_{2} \mathrm{O}_{3}$-NP-administrated rats was compared to control (Table 2). In contrast, there was a significant decline in the comet parameters of PSO and $\mathrm{Al}_{2} \mathrm{O}_{3}$-NPs co-administrated rats, thus PSO alleviating $\mathrm{Al} 2 \mathrm{O} 3-\mathrm{NPs}$ toxicity.

\section{Effect of PSO and/or $\mathrm{Al}_{2} \mathrm{O}_{3}$-NPs on serum levels of testosterone}

Serum levels of testosterone significantly declined $(p<$ .05) in $\mathrm{Al}_{2} \mathrm{O}_{3}$-NP-administrated rats when compared to control rats. Furthermore, serum testosterone concentration in $\mathrm{PSO}$ and $\mathrm{Al}_{2} \mathrm{O}_{3}$-NPs co-administrated rats was significantly elevated $(p<.05)$, compared to $\mathrm{Al}_{2} \mathrm{O}_{3}-\mathrm{NP}$ administrated rat (Fig. 3).

\section{Effect of PSO on $\mathrm{Al}_{2} \mathrm{O}_{3}$-NP-induced oxidative stress in the testicular tissue}

Al2O3-NP-administrated rat showed a marked increase $(p<.05)$ of MDA and a decline in GSH content and CAT activities in the testicular homogenates, as compared to control rat. PSO-administrated rat revealed a significant change in the levels of the aforementioned

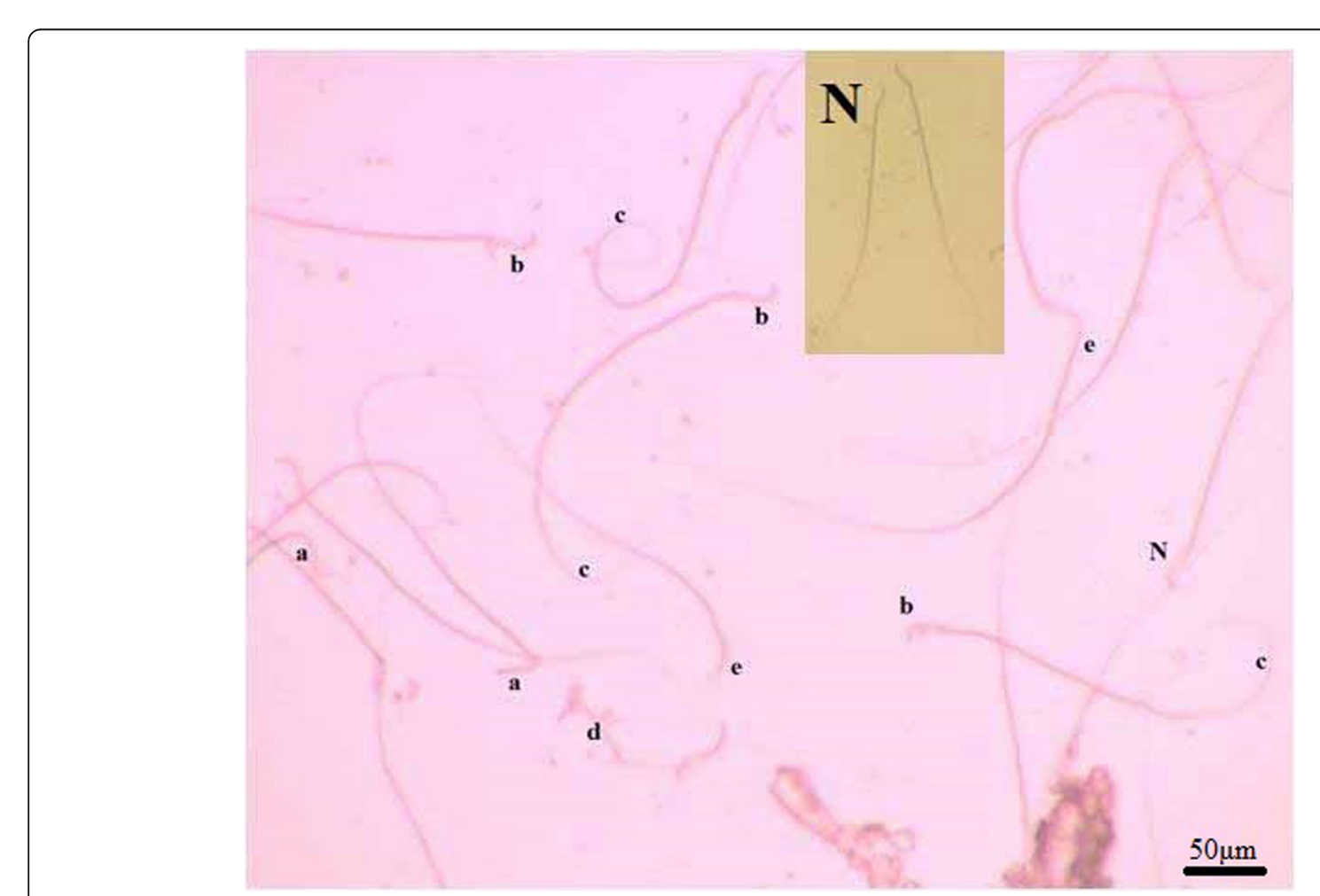

Fig. 1 Photomicrograph showing sperm morphology from the cauda epididymis of male albino rats. (N) normal sperm; (a) bent head; (b) banana head; (c) coiled tail; (d) detached head; (e) headless sperm. Eosin stain 

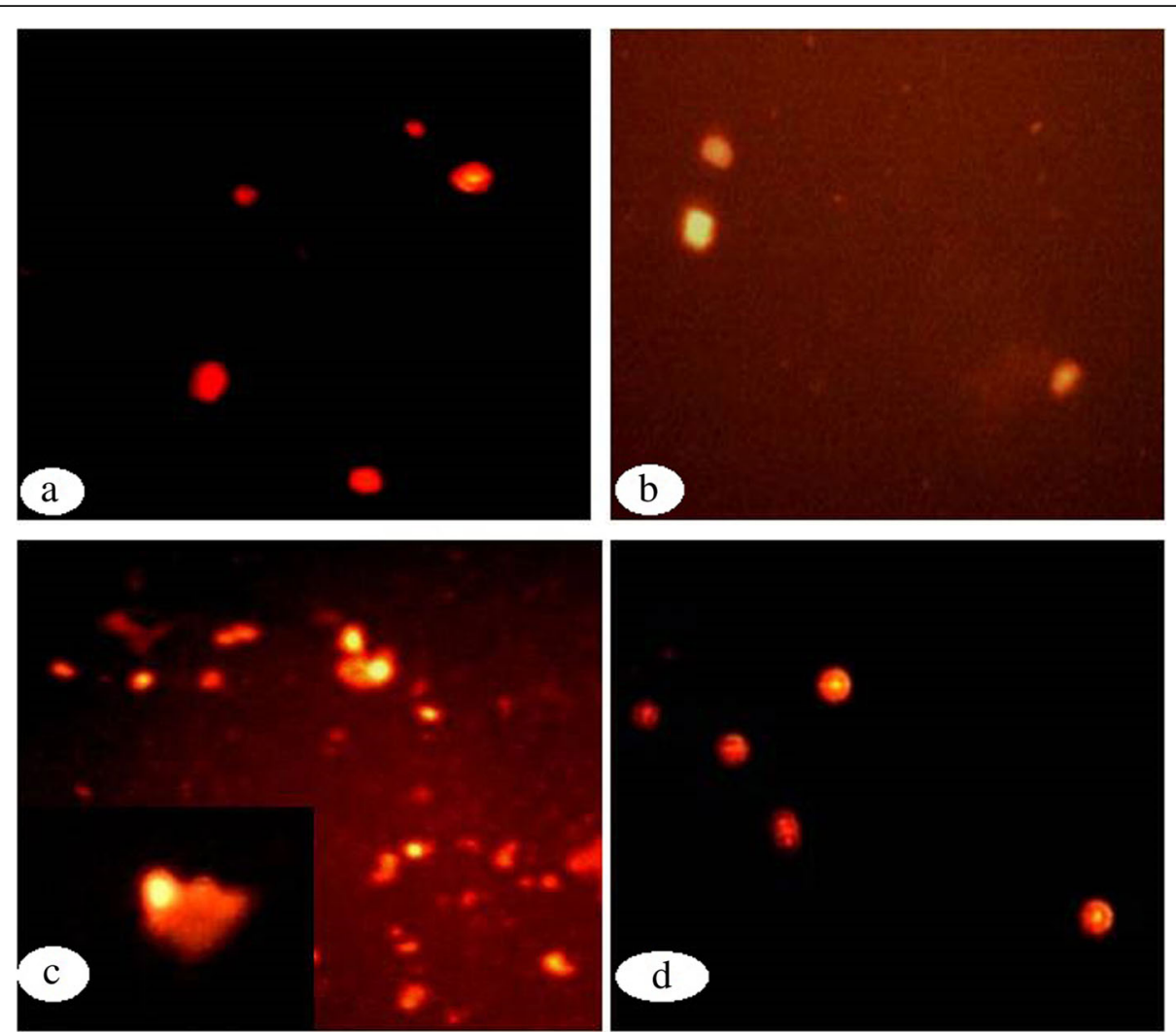

Fig. 2 Photomicrographs of comet assay showing $(\mathbf{a}, \mathbf{b})$ typical nuclei of undamaged testicular cells of control and PSO groups. $\mathbf{c}$ DNA damage observed as comets that were seen in the $\mathrm{Al}_{2} \mathrm{O}_{3}-\mathrm{NP}$ group and $\mathbf{d}\left(\mathrm{PSO}+\mathrm{Al}_{2} \mathrm{O}_{3}-\mathrm{NP}\right)$ group

oxidative stress markers. Meanwhile, PSO in combination with $\mathrm{Al}_{2} \mathrm{O}_{3}$-NPs reestablished the oxidant/antioxidant balance in the homogenates of the testes of $\mathrm{Al}_{2} \mathrm{O}_{3}$ NP-administered rat (Figs. 4, 5, and 6).

\section{Histopathological examination}

Figure 7 showed the photomicrographs of the testes from the different groups. The seminiferous tubules with normal structure showed regularly arranged rows and complete set of germinal epithelium in both control and pumpkin seed oil groups as seen in Fig. $7 \mathrm{a}$ and b. Otherwise, seminiferous tubules of $\mathrm{Al}_{2} \mathrm{O}_{3}$-NP-administrated rats showed vacuolization and degenerative and necrotic changes specially in spermatogonial cell layer and in some areas of the germinal epithelium as well as interstitial edema and congestion of blood vessels (Fig. 7c). In PSO and $\mathrm{Al}_{2} \mathrm{O}_{3}$-NP co-administrated rats, amelioration in histopathological examination was seen in testicular tissues (Fig. 7d), where examined sections revealed no histopathological alterations.

\section{Immunohistochemistry for caspase-3}

Figure 8 showed the photomicrographs of the testes from the different groups. The intensity of activated caspase-3 immunostaining (brown) is predominant on seminiferous tubules and Leydig cells of $\mathrm{Al}_{2} \mathrm{O}_{3}$-NP-administrated rats. In $\mathrm{PSO}$ and $\mathrm{Al}_{2} \mathrm{O}_{3}$-NP co-administrated rats, the immunostaining was mitigated by PSO.

Table 2 Effect of pumpkin seed oil on the percentage of DNA damage (\%DNA), tail length (TL), and tail moment (TM), in the testicular tissue of rat administrated with $\mathrm{Al}_{2} \mathrm{O}_{3}-\mathrm{NPS}$

\begin{tabular}{|c|c|c|c|c|}
\hline \multirow[t]{2}{*}{ Parameter } & \multicolumn{4}{|c|}{ Experimental groups } \\
\hline & Control & PSO & $\mathrm{Al}_{2} \mathrm{O}_{3}-\mathrm{NPS}$ & $\mathrm{PSO}+\mathrm{Al}_{2} \mathrm{O}_{3}-\mathrm{NPS}$ \\
\hline DNA\% tail & $15.59 \pm 0.5653$ & $15.33 \pm 0.2822$ & $34.12 \pm 2.491^{a}$ & $22.93 \pm 1.257^{b}$ \\
\hline Tail length ( $\mu \mathrm{m})$ & $5.113 \pm 0.3702$ & $4.943 \pm 0.0348$ & $24.31 \pm 0.8417^{a}$ & $11.01 \pm 0.3405^{b}$ \\
\hline Tail moment $(\mu \mathrm{m})$ & $1.083 \pm 0.3346$ & $1.031 \pm 0.2924$ & $5.827 \pm 0.4737^{a}$ & $2.936 \pm 0.2135^{b}$ \\
\hline
\end{tabular}

${ }^{a}$ Refers to a significant change from the control rat

${ }^{\mathrm{b}}$ Refers to a significant change from the Al2O3-NP-administrated rat 


\section{Testosterone(ng/mg)}

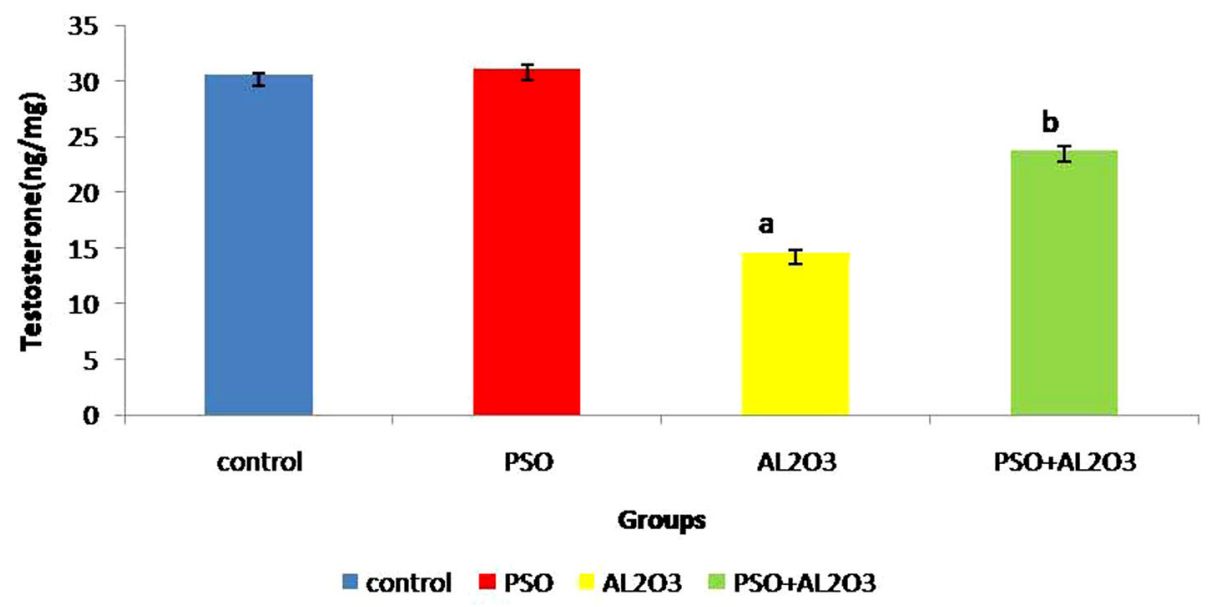

Fig. 3 Effect of pumpkin seed oil on serological testosterone level in $\mathrm{AL}_{2} \mathrm{O}_{3}-\mathrm{NP}$ administrated rat. (a) Significant change from the control rat. (b) Significant change from the $\mathrm{AL}_{2} \mathrm{O}_{3}-\mathrm{NP}$-administrated rat

\section{Discussion}

NPs possess the ability to cross the blood-testis barrier (BTB) that protects reproductive tissue (Bai et al., 2010; Gao et al., 2013). Hussein, Ali, Saadeldin, and Ahmed (2016) reported that many NPs can cross the BTB and exert their toxic impacts on spermatogenesis. Regarding accumulation and translocation, the capacity of NPs to penetrate both the BTB and the blood-brain barrier is very important (Araujo, Sheppard, Löbenberg, \& Kreuter, 1999; Kim et al., 2006).
Lin et al. (2007) showed that $\mathrm{SiO} 2$ NPs decreased sperm count and the sperm mobility rate and significantly increased the malformation rate, in the testis of rat after intraperitoneal injection. Guo et al. $(2009,2010)$ observed that $\mathrm{TiO} 2 \mathrm{NPs}$ and/or $\mathrm{ZnO}$ NPs significantly reduced sperm density and motility, and increased sperm abnormality and germ cell apoptosis in the testis of male mouse after intraperitoneal injection. Zhou, Yue, Li, Zhou, and Liu (2019) showed that PbSe-NP administration led to reduction in the quantity and quality of

\section{MDA(nmol/g)}

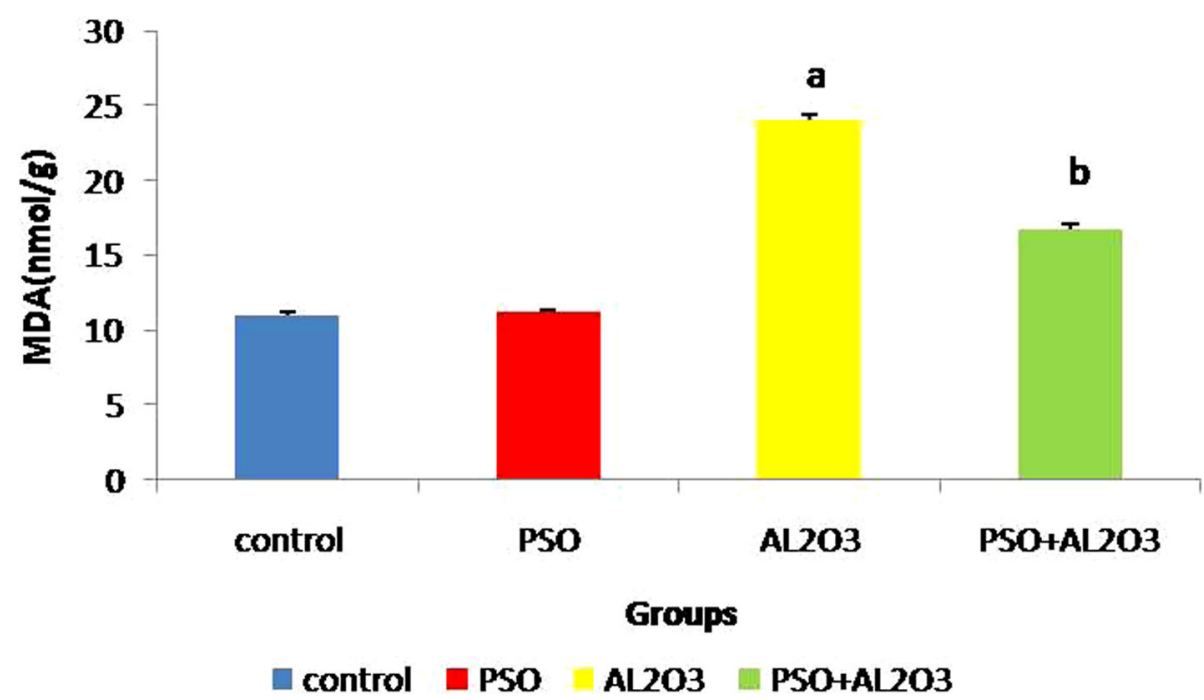

Fig. 4 Effect of pumpkin seed oil on lipid peroxidation (MDA level) in testicular tissue of $\mathrm{AL}_{2} \mathrm{O}_{3}-\mathrm{NP}$ administrated rat. (a) Significant change from the control rat. (b) Significant change from the $\mathrm{AL}_{2} \mathrm{O}_{3}-\mathrm{NP}$-administrated rat 


\section{$\mathrm{GSH}(\mathrm{mmol} / \mathrm{g})$}

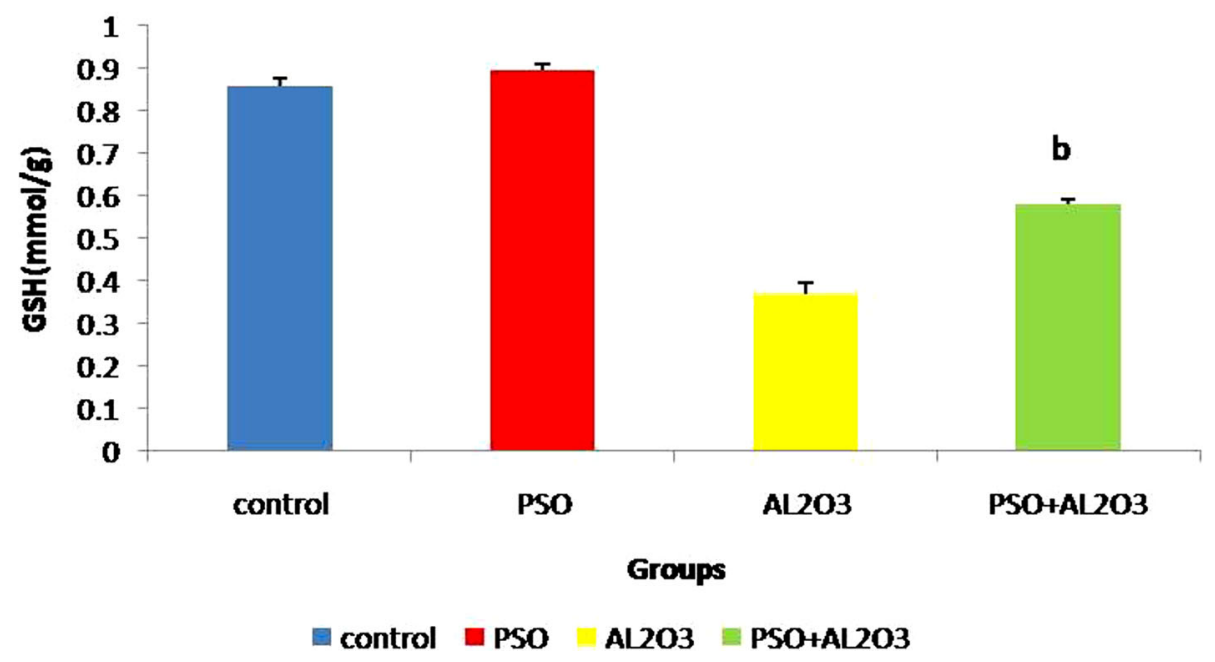

Fig. 5 Effect of pumpkin seed oil on the level of glutathione reduced (GSH) in testicular tissue of AL2O3-NP administrated rat. (a) Significant change from the control rat. (b) Significant change from the AL2O3-NP administrated rat

sperm; accumulation of PbSe-NPs caused oxidative stress, disorder of normal serum sex hormones, endoplasmic reticulum, and mitochondria-mediated cell apoptosis which caused a significant decline in fertility.

Brezina, Yunus, and Zhao (2012) reported that male infertility can be evaluated by using semen parameters as concentration, motility, and spermatozoa morphology. In the current work, reproductive toxicity of $\mathrm{Al}_{2} \mathrm{O}_{3}-\mathrm{NPs}$ was characterized by a significant decrease in the concentration and normal morphology of spermatozoa, significant increase in DNA damage, histopathological alterations, and increase in intensity of caspase3expression. MDA is a lipid peroxidation by-product, which could indirectly indicate the severity of injured tissues (Sreelatha, Padma, \& Umadevi, 2009; Yu et al., 2011). To confirm oxidative injury caused by the accumulation of $\mathrm{Al}_{2} \mathrm{O}_{3}$-NPs in the testes, MDA levels were determined. There was a significant increment in

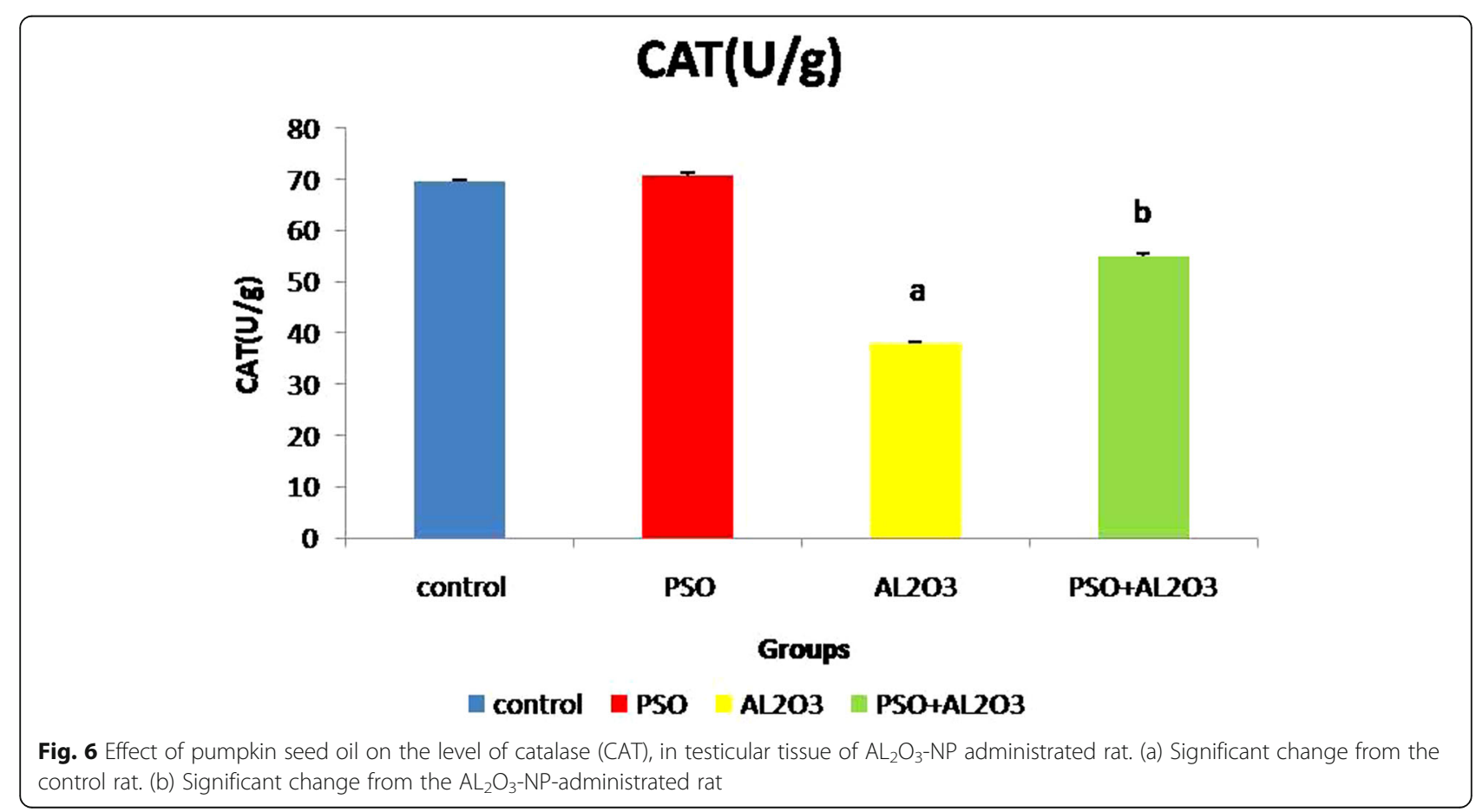




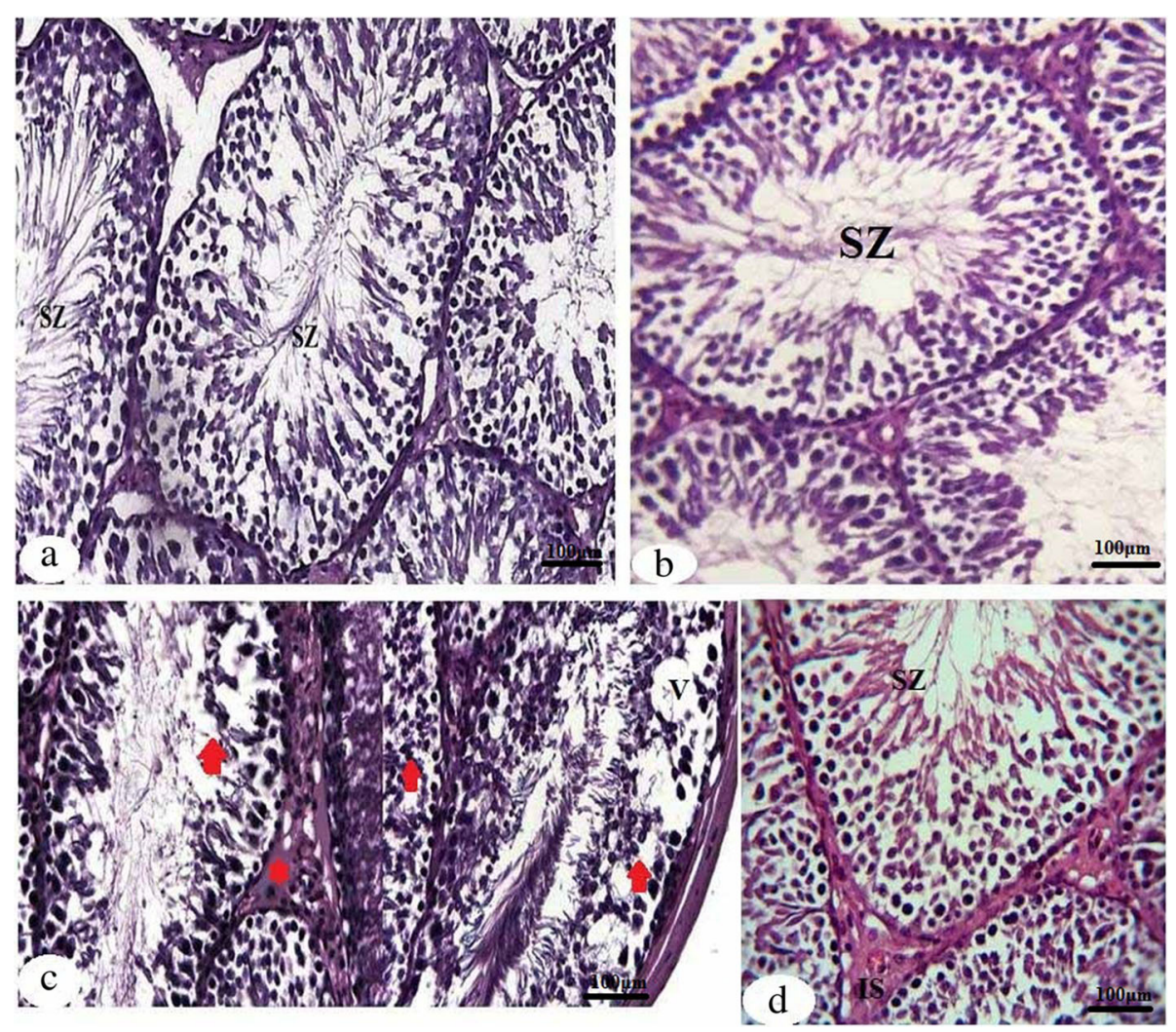

Fig. 7 Photomicrographs of testicular sections of different groups, hematoxylin, and eosin. $\mathbf{a}$, $\mathbf{b}$ Testicular sections from control and PSO groups, respectively, showing normal histological features of seminiferous tubules. c Testicular section from $\mathrm{Al}_{2} \mathrm{O}_{3}$-administrated rat showing the degenerative, vacuolization, and necrotic changes specially in spermatogonial cell layer and in some areas of the germinal epithelium as well as interstitial edema and congestion of blood vessels (arrows), interstitial edema, (asterisk) $\mathbf{d}$ testicular section from the co-administrated group with PSO and $\mathrm{Al}_{2} \mathrm{O}_{3}$ showing an obvious preservation of spermatogenic epithelium in most seminiferous tubules. SZ, spermatozoa, IS, interstitial cells

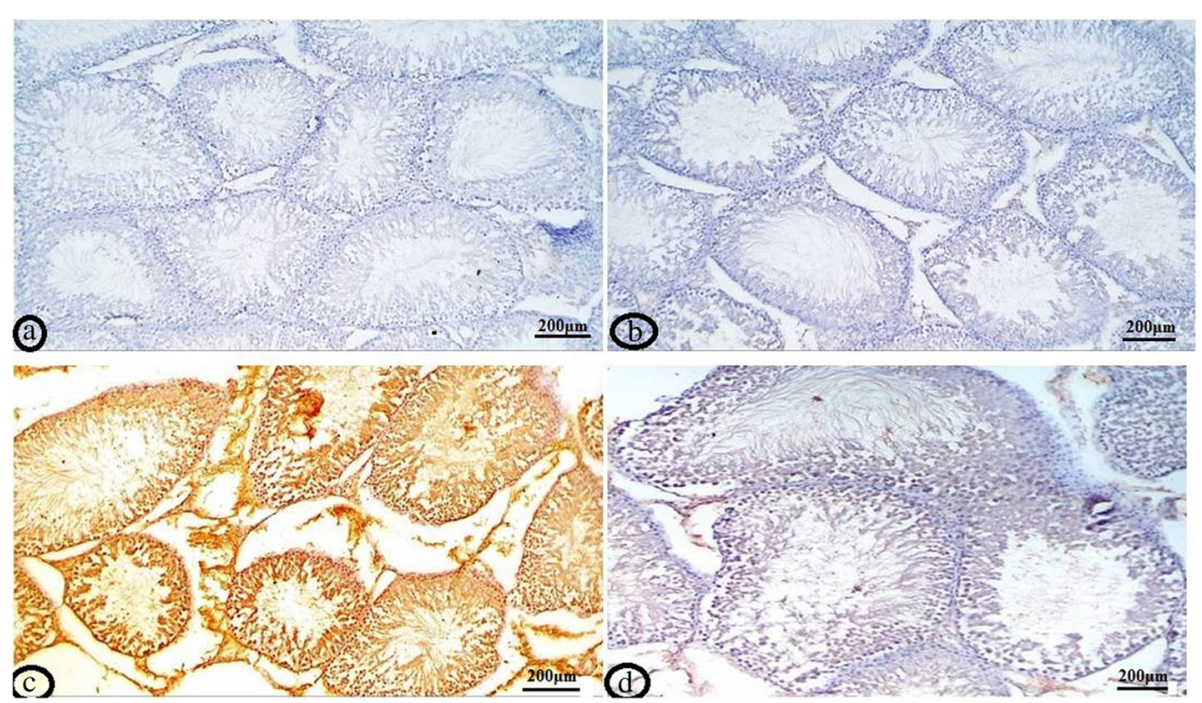

Fig. 8 Immunohistochemical staining of activated caspase-3 in rat testis. a Testis of control rats. b Testis of PSO-administered rats. c Testis of $\mathrm{Al}_{2} \mathrm{O}_{3}$-administrated rats. The intensity of activated caspase-3 immunostaining(brown color) is pre-dominant on spermatogonia and Leydig cells in $\mathrm{Al}_{2} \mathrm{O}_{3}$-administered group. $\mathbf{d}$ Testis of $\mathrm{PSO}+\mathrm{Al}_{2} \mathrm{O}_{3}$ co-administered rats 
testicular MDA when compared with the control group. Furthermore, the administration of Al2O3-NPs resulted in a significant decline in testicular GSH and CAT. It is suggested that Al2O3-NPs could decrease the quantity/ quality of sperm through cellular impairment of testicular tissue, which is caused by the generation of ROS. These data are in agreement with former results (Morsy et al., 2016a, 2016b, 2016c), administration of $\mathrm{Al}_{2} \mathrm{O}_{3}$ NPs generates a state of oxidative stress in the brain, liver, and kidney tissues of rats, shown by lipid peroxidation increment and antioxidant defense system compromised.

Ema, Kobayashi, Naya, Hanai, and Nakanishi (2010) indicated that in vitro studies revealed that silver, aluminum, and molybdenum trioxide NPs injured spermatogonia stem cells; $\mathrm{TiO} 2$ and black carbon nanoparticles (CB NPs) impacted Leydig cell viability, and gold NPs reduced human sperm motility. Yoshida et al. (2009) observed that black carbon nanoparticles have adverse impacts on male reproductive function in mice characterized by elevated serum testosterone $(\mathrm{T})$ levels and histological alterations in both the seminiferous tubules and Sertoli cells such as vacuolation and degenerative changes and Leydig cell dysfunction.

Lan and Yang (2012) stated that the Leydig cells secrete testosterone, an essential hormone for spermatogenesis. Leydig and Sertoli cell apoptosis through DNA damage was reported in vitro after incubation with ZnONPs (Han et al., 2016) and in vivo after exposure to AgNPs (Castellini et al., 2014; Layali, Tahmasbpour, \& Jorsaraei, 2016). Lan and Yang (2012) reported that NP exposure may induce a generalized inflammation in the host and affect Leydig cells, causing decline in testosterone serum levels, which then impaired the integrity of the BTB. In conformity with former findings (Castellini et al., 2014; Ema et al., 2010; Lan \& Yang, 2012; Layali et al., 2016), administration of $\mathrm{Al}_{2} \mathrm{O}_{3}$-NPs caused the reduction in serum testosterone level and histological alterations such as vacuolation and degenerative changes in the seminiferous tubules.

In conformity with former work (Guo et al., 2009 \& 2010; Zhou et al., 2019), administration of $\mathrm{Al}_{2} \mathrm{O}_{3}-\mathrm{NPs}$ caused increase in intensity of caspase- 3 expression which is ultimately responsible for the majority of the cell apoptotic process.

Liu et al. (2016) suggested the reproductive toxicity of $\mathrm{ZnO}$ NPs using a mouse Sertoli cell line (TM-4) and spermatocyte cell line (GC2-spd) characterized by generating ROS and DNA lesions in germ cells. ZnO NPs could exert their toxicity by downregulating the gap junction protein expression and disrupting the Sertoli cell mitochondrial outer membrane and cell membrane, potentially leading to BTB disruption and further destroying BTB integrity. Furthermore, ROS and the cytokine secretion play important roles in BTB disruption, significant increment in the status of oxidative stress (i.e., leading to ROS and MDA increment and GSH decline), and increasing the cytokine (TNF- $\alpha$ ) levels in Sertoli cells.

The induction of sperm abnormalities could be attributed to oxidative stress and lipid peroxidation (Agarwal \& Saleh, 2002). Plasma membrane of the spermatozoa is liable to peroxidation due to the high extent of unsaturated fatty acids and low antioxidant capacity. The lipid peroxidation disrupts the structure of the lipid matrix in the membrane of spermatozoa, causing the motility loss and the membrane integrity defects (Vernet, Aitken, \& Drevet, 2004).

Morsy et al. (2016a, 2016b) showed that nanoalumina injection for male rats induced the oxidative stress (MDA increment and GSH, and CAT decline) in the brain, hepatic, and renal tissues, leading to DNA damage and histopathological alterations.

It is believed that NPs are absorbed in the testis in their ionic form. Accumulation of $\mathrm{Al}$ in the testis can partially contribute to the toxicity of $\mathrm{Al}_{2} \mathrm{O}_{3}$-NPs. Human and animal exposure to $\mathrm{Al}$-containing products will increase the concentration of this metallic element in their organs and damage their tissues (including the testicular tissues). Yousef, Kamel, El-Guendi, and El-Demerdash (2007) and Guo, Lin, Yeh, and Hsu (2005, b) reported sperm viability and motility reduction due to the high levels of $\mathrm{Al}$ in spermatozoa and seminal plasma. Sharma et al. (2003), Guo et al. (2005, b), and Cheraghi, Golkar, Roshanaei, and Alani (2017) showed accumulation of Al in testicular tissue, necrosis of spermatocytes/spermatids, and a significant decline in fertility in both male rats and mice. Al may exert its toxicity in reproductive system of male through various mechanisms such as generating oxidative stress, interfering with spermatogenesis and steroidogenesis, impairing cell signaling, BTB, and disrupting the endocrine system (Pandey \& Jain, 2013).

This observation could be attributed to the ability of $\mathrm{Al}^{+3}$ and $\mathrm{Al}_{2} \mathrm{O}_{3}-\mathrm{NPs}$ to induce oxidative stress, penetrate the $\mathrm{BTB}$, generate lipid peroxidation, and ultimately injure the testis biological membrane. The low sperm count, motility, and viability, as well as the high morphological abnormality, DNA damage, and histological alterations shown in $\mathrm{Al}_{2} \mathrm{O}_{3}$-NP-administered rats, confirm the previous findings.

Pumpkin seed oil is known to increase membrane fluidity and osmosis and allows for intracellular and extracellular gaseous exchange, attributed to the presence of linoleic acid, a polyunsaturated fatty acid (Lovejoy, 2002). In addition, pumpkin diminishes the ability of the testes and epididymis to lipid peroxidation due to the presence of oleic acid, a monounsaturated fatty acid 
(Bourre, Dumont, \& Durand, 2004; Lovejoy, 2002). Pumpkin seed oil possesses some fundamental constituents (vitamin A, tannins, linoleic acid, oleic acid, and alkaloids) which inhibit lipid peroxidation, hence, attenuating testicular function (Akintayo, 1997; Bensoussan, Morales, \& Hermo, 1998; Leat, Northrop, Harrison, \& Cox, 1983). From the present data, it can be suggested that pumpkin seed oil may be used as antioxidant against testicular toxicity which might be induced by $\mathrm{Al}_{2} \mathrm{O}_{3}$-NPs administration. Akang, Oremosu, Dosumu, Noronha, and Okanlawon (2010) demonstrated that pumpkin seed oil attenuated semen parameters and testicular histopathology. Nkang, Omokaro, Egbe, and Amanke (2003) reported that PSO contains a natural, potent-free radical quencher, singlet scavenger and lipid antioxidant, vitamin A, B-carotene, and tannins. Fukuchi et al. (2004) and Salman, Olayaki, and Oyeyemi (2008) reported that vitamin A reduces the capability of the testis to lipid peroxidation, hence, improves spermatogenesis; this elucidates the increase in sperm concentration in the pumpkin-administrated groups. Phenolic compounds, vitamins, and zinc in pumpkin are neutralizing free radical generation by its antioxidant action (Amara et al., 2008; Morakinyo, Achema, \& Adegoke, 2010(. Akang et al. (2010) demonstrated that pumpkin seed oil attenuated semen parameter level of testosterone hormone in male rats, has a prophylactic effect on alcohol-induced testicular injury, and has ameliorated semen quality.

\section{Conclusion}

According to the current data, it could be concluded that PSO exhibits its protective role by inhibiting cellular damage and apoptosis occurring as a result of oxidative stress in the spermatogenic cells of seminiferous tubules and Leydig cells induced by the administration of $\mathrm{Al}_{2} \mathrm{O}_{3}$ nanoparticles.

\section{Abbreviations \\ AgNPs: Silver nanoparticles; Al: Aluminum; $\mathrm{Al}_{2} \mathrm{O}_{3} \mathrm{NPs}$ : Aluminum oxide nanoparticles; BTB: Blood-testis barrier; CAT: Catalase; CB NPs: Black carbon nanoparticles; DNA: Deoxyribonucleic acid; ELISA: The enzyme-linked im- munosorbent assay; GSH: Glutathione; H\&E: Hematoxylin and eosin; MDA: Malondialdehyde; NPS: Nanoparticles; PBS: Phosphate-buffered saline; PbSe NPs: Lead selenide nanoparticles; PSO: Pumpkin seed oil; \\ $\mathrm{T}$ : Testosterone; TiO2: Titanium dioxide nanoparticles; ROS: Robot Operating System; ZnO NPs: Zinc oxide nanoparticles}

\section{Acknowledgements}

Not applicable

\section{Author's contributions}

The author did all the work and read and approved the final manuscript.

\section{Funding}

The present study was self-funded by the author.

\section{Availability of data and materials}

The datasets analyzed during the current study are available from the corresponding author on reasonable request.

Ethics approval and consent to participate

The study was carried out in strict accordance with the Guide for the Care and Use of Laboratory Animals 8th Edition 2011.

Consent for publication

Not applicable

\section{Competing interests}

No potential conflict of interest was reported by the author.

Received: 14 May 2020 Accepted: 15 June 2020

Published online: 29 June 2020

\section{References}

Aebi, H. (1984). Catalase in vitro. Methods of Enzymology, 105, 121-126.

Agarwal, A., \& Saleh, R. A. (2002). Role of oxidants in male infertility: rationale, significance, and treatment. The Urologic Clinics of North America, 29(4), 817827

Akang, E. N., Oremosu, A. A., Dosumu, O. O., Noronha, C. C., \& Okanlawon, A. O. (2010). The effect of fluted pumpkin (Telferia occidentalis) seed oil (FPSO) on testis and semen parameters. Agriculture and Biology Journal of North America, 1(4), 697-703.

Akintayo, E. T. (1997). Chemical composition and physicochemical properties of fluted pumpkin (Telfairia occidentalis) seed and seed oils. Rivista Italiana Delle Sostanze Grasse, 74(1), 13-15.

Al-Zuhair, H., Abd el-Fattah, A. A., \& Abd el Latif, H. A. (1997). Efficacy of simvastatin and pumpkin-seed oil in the management of dietary-induced hypercholesterolemia. Pharmacological Research, 35(5), 403-408.

Amara, S., Abdelmelek, H., Garrel, C., Guiraud, P., Douki, T., Ravanat, J. L., ... Ben Rhouma, K. (2008). Preventive effect of zinc against cadmium-induced oxidative stress in the rat testis. The Journal of Reproduction and Development, $54(2), 129-134$

Andjelkov, M., Camp, J. V., Trawka, A., \& Verhe, R. (2010). Phenolic compounds and some quality parameters of pumpkin seed oil. European Journal of Lipid Science and Techology, 112(2), 208-217.

Araujo, L., Sheppard, M., Löbenberg, R., \& Kreuter, J. (1999). Uptake of PMMA nanoparticles from the gastrointestinal tract after oral administration to rats: Modification of the body distribution after suspension in surfactant solutions and in oil vehicles. International Journal of Pharmaceutics, 176(2), 209-224.

Arul Prakash, F., Dushendra Babu, G. J., Lavanya, M., Vidhya, K. S., \& Devasena, T. (2011). Toxicity studies of aluminium oxide nanoparticles in cell lines. International Journal of Nanotechnology and Application, 5, 99-107.

Bai, Y., Zhang, Y., Zhang, J., Mu, Q., Zhang, W., Butch, E. R., ... Yan, B. (2010). Repeated administrations of carbon nanotubes in male mice cause reversible testis damage without affecting fertility. Nature Nanotechnology, 5(9), 683689

Balasubramanyam, A., Sailaja, N., Mahboob, M., Rahman, M. F., Hussain, S. M., \& Grover, P. (2009). In vivo genotoxicity assessment of aluminium oxide nanomaterials in rat peripheral blood cells using the comet assay and micronucleus test. Mutagenesis, 24(3), 245-251.

Bancroft, J. D., \& Gamble, M. (2008). Theory and practice of histological techniques, (6th ed., ). Edinburgh: Churchill Livingstone.

Bartsch, M., Saruhan, B., Schmücker, M., \& Schneider, H. (1999). Novel lowtemperature processing route of dense mullite ceramics by reaction sintering of amorphous $\mathrm{SiO} 2$-coated $\mathrm{\gamma}-\mathrm{Al}_{2} \mathrm{O}_{3}$ particle nanocomposites. Journal of the American Ceramic Society, 82(6), 1388-1392.

Bensoussan, K., Morales, C. R., \& Hermo, L. (1998). Vitamin E deficiency causes incomplete spermatogenesis and affects the structural differentiation of epithelial cells of the epididymis in the rat. Journal of Andrology, 19(3), 266288

Beutler, E., Duron, O., \& Kelly, M. B. (1963). Improved method for the determination of blood glutathione. Journal of Laboratory and Clinical Medicine, 61, 882-888.

Beyzay, F., Zavaran Hosseini, A., \& Soudi, S. (2017). Alpha alumina nanoparticle conjugation to cysteine peptidase A and B: An efficient method for autophagy induction. Avicenna Journal of Medical Biotechnology, 9(2), 71-81. 
Borbane, S. A., Pande, V. V., Vibhute, S. K., Kendre, P. N., \& Dange, V. U. (2015). Design and fabrication of ordered mesoporous alumina scaffold for drug delivery of poorly water soluble drug. Austin Therapeutics, 2(1), 1015.

Bourre, J. M., Dumont, O., \& Durand, G. (2004). Dose-effect of dietary oleic acid: Oleic acid is conditionally essential for some organs. Reproduction, Nutrition, Development, 44(4), 371-380.

Brezina, P. R., Yunus, F. N., \& Zhao, Y. (2012). Effects of pharmaceutical medications on male fertility. Journal of Reproduction and Infertility, 13, 3-11.

Caili, F., Huan, S., \& Quanhong, L. (2006). A review on pharmacological activities and utilization technologies of pumpkin. Plant Foods for Human Nutrition (Dordrecht, Netherlands), 61(2), 73-80.

Castellini, C., Ruggeri, S., Mattioli, S., Bernardini, G., Macchioni, L., Moretti, E., \& Collodel, G. (2014). Long-term effects of silver nanoparticles on reproductive activity of rabbit buck. Systems Biology in Reproductive Medicine, 60(3), 143150.

Chen, L., Yokel, R. A., Hennig, B., \& Toborek, M. (2008). Manufactured aluminum oxide nanoparticles decrease expression of tight junction proteins in brain vasculature. Journal of Neuroimmune Pharmacology, 3(4), 286-295.

Cheraghi, E., Golkar, A., Roshanaei, K., \& Alani, B. (2017). Aluminium-induced oxidative stress, apoptosis and alterations in testicular tissue and sperm quality in Wistar rats: Ameliorative Effects of curcumin. International Journal of Fertility \& Sterility, 11(3), 166-175

Dey, S., Bakthavatchalu, V., Tseng, M. T., Wu, P., Florence, R. L., Grulke, E. A., ... St Clair, D. K. (2008). Interactions between SIRT1 and AP-1 reveal a mechanistic insight into the growth promoting properties of alumina (Al2O3) nanoparticles in mouse skin epithelial cells. Carcinogenesis, 29(10), 1920-1929.

Duan, W. R., Garner, D. S., Williams, S. D., Funckes-Shippy, C. L., Spath, I. S., \& Blomme, E. A. (2003). Comparison of immunohistochemistry for activated caspase- 3 and cleaved cytokeratin 18 with the TUNEL method for quantification of apoptosis in histological sections of PC-3 subcutaneous xenografts. The Journal of Pathology, 199(2), 221-228.

Elfiky, S. A., Elelaimy, I. A., Hassan, A. M., Ibrahim, H. M., \& Elsayad, R. I. (2012) Protective effect of pumpkin seed oil against genotoxicity induced by azathioprine. Journal of Basic and Applied Zoology, 65, 289-298.

Ema, M., Kobayashi, N., Naya, M., Hanai, S., \& Nakanishi, J. (2010). Reproductive and developmental toxicity studies of manufactured nanomaterials. Reproductive Toxicology (Elmsford, N.Y.), 30(3), 343-352.

Fahim, A. T., Abd-el Fattah, A. A., Agha, A. M., \& Gad, M. Z. (1995). Effect of pumpkin-seed oil on the level of free radical scavengers induced during adjuvant-arthritis in rats. Pharmacological Research, 31(1), 73-79.

Feng, X., Chen, A., Zhang, Y., Wang, J., Shao, L., \& Wei, L. (2015). Application of dental nanomaterials: Potential toxicity to the central nervous system. International Journal of Nanomedicine, 10, 3547-3565.

Frey, A., Neutra, M. R., \& Robey, F. A. (1997). Peptomer aluminum oxide nanoparticle conjugates as systemic and mucosal vaccine candidates: Synthesis and characterization of a conjugate derived from the C4 domain of HIV-1MN gp120. Bioconjugate Chemistry, 8(3), 424-433.

Fruhwirth, G. O., \& Hermetter, A. (2007). Seeds and oil of the Styrian oil pumpkin: Components and biological activities. European Journal of Lipid Science and Techology, 109(11), 1128-1140

Fukuchi, S., Hamaguchi, K., Seike, M., Himeno, K., Sakata, T., \& Yoshimatsu, H. (2004). Role of fatty acid composition in the development of metabolic disorders in sucrose-induced obese rats. Experimental Biology and Medicine (Maywood, N.J.), 229(6), 486-493.

Gao, G., Ze, Y., Zhao, X., Sang, X., Zheng, L., Ze, X., ... Zhang, X. (2013). Titanium dioxide nanoparticle-induced testicular damage, spermatogenesis suppression, and gene expression alterations in male mice. Journal of Hazardous Materials, 258-259, 133-143.

Guo, C. H., Lin, C. Y., Yeh, M. S., \& Hsu, G. S. (2005). Aluminum-induced suppression of testosterone through nitric oxide production in male mice. Environmental Toxicology and Pharmacology, 19(1), 33-40.

Guo, C. H., Lu, Y. F., \& Hsu, G. S. (2005). The influence of aluminum exposure on male reproduction and offspring in mice. Environmental Toxicology and Pharmacology, 20(1), 135-141.

Guo, L. L., Liu, X. H., Gao, L., Qin, D. X., Zhang, H. M., Liu, J. Y., \& Cui, Y. G. (2010). Study on the effect of nanosized titanium dioxide for reproductive system of male mice. J Med Postgrad, 4, 357-364 Article serial number: 1008-8199 (2010)04-0357-08 (In Chinese with English abstract).

Guo, L. L., Liu, X. H., Qin, D. X., Gao, L., Zhang, H. M., Liu, J. Y., \& Cui, Y. G. (2009). Effects of nanosized titanium dioxide on the reproductive system of male mice. Zhonghua Nan Ke Xue, 15, 517-522 (in Chinese).
Han, Z., Yan, Q., Ge, W., Liu, Z. G., Gurunathan, S., De Felici, M., ... Zhang, X. F. (2016). Cytotoxic effects of $\mathrm{ZnO}$ nanoparticles on mouse testicular cells. International Journal of Nanomedicine, 11, 5187-5203.

Hussein, M. M., Ali, H. A., Saadeldin, I. M., \& Ahmed, M. M. (2016). Quercetin alleviates zinc oxide nanoreprotoxicity in male albino rats. Journal of Biochemical and Molecular Toxicology, 30(10), 489-496.

Kim, J. S., Yoon, T. J., Yu, K. N., Kim, B. G., Park, S. J., Kim, H. W., ... Cho, M. H. (2006). Toxicity and tissue distribution of magnetic nanoparticles in mice. Toxicological Sciences, 89(1), 338-347.

Lan, Z., \& Yang, W. X. (2012). Nanoparticles and spermatogenesis: how do nanoparticles affect spermatogenesis and penetrate the blood-testis barrier Nanomedicine (London, England), 7(4), 579-596.

Layali, E., Tahmasbpour, E., \& Jorsaraei, S. (2016). The effects of silver nanoparticles on oxidative stress and sperm parameters quality in male rats. Journal of Babol University of Medical Sciences, 18(2), 48-55.

Leat, W. M., Northrop, C. A., Harrison, F. A., \& Cox, R. W. (1983). Effect of dietary linoleic and linolenic acids on testicular development in the rat. Quarterly Journal of Experimental Physiology (Cambridge, England), 68(2), 221-231.

Li, X. B., Zheng, H., Zhang, Z. R., Li, M., Huang, Z. Y., Schluesener, H. J., ... Xu, S. Q. (2009). Glia activation induced by peripheral administration of aluminum oxide nanoparticles in rat brains. Nanomedicine: Nanotechnology, Biology and Medicine, 5(4), 473-479.

Lin, C., Xi, Z. G., Zhang, Y. G., Zhang, H. S., Yang, D. F., Sun, X., ... Liu, H. L. (2007). Experimental study on the reproductive damage of male rats induced by micronano-scale SiO2. Asian Journal of Ecotoxicology, 2(2), 195-201 (in Chinese).

Liu, Q., Xu, C., Ji, G., Liu, H., Mo, Y., Tollerud, D. J., ... Zhang, Q. (2016). Sublethal effects of zinc oxide nanoparticles on male reproductive cells. Toxicology in vitro: an international journal published in association with BIBRA, 35, 131-138.

Lovejoy, J. C. (2002). The influence of dietary fat in insulin resistance. Current Diabetes Reports, 2(5), 430-440.

Morakinyo, A. O., Achema, P. U., \& Adegoke, O. A. (2010). Effect of zingiber officinale (Ginger) on sodium arsenite induced reproductive toxicity in male rats. African Journal of Biomedical Research, 13(1), 39-45.

Morsy, G. M., Abou El-Ala, K. S., \& Ali, A. A. (2016a). Studies on fate and toxicity of nanoalumina in male albino rats: Oxidative stress in the brain, liver and kidney. Toxicology and Industrial Health, 32(2), 200-214.

Morsy, G. M., Abou El-Ala, K. S., \& Ali, A. A. (2016b). Studies on fate and toxicity of nanoalumina in male albino rats: Lethality, bioaccumulation and genotoxicity. Toxicology and Industrial Health, 32(2), 344-359.

Morsy, G. M., Abou El-Ala, K. S., \& Ali, A. A. (2016c). Studies on fate and toxicity of nanoalumina in male albino rats: Some haematological, biochemical and histological aspects. Toxicology and Industrial Health, 32(4), 634-655.

Nandhakumar, S., Parasuraman, S., Shanmugam, M. M., Rao, K. R., Chand, P., \& Bhat, B. V. (2011). Evaluation of DNA damage using single-cell gel electrophoresis (Comet Assay). Journal of Pharmacology and Pharmacotherapeutics, 2(2), 107-111.

Nkang, A., Omokaro, D., Egbe, A., \& Amanke, G. (2003). Variations in fatty acid proportions during desiccation of Telfairia occidentalis seeds harvested at physiological and agronomic maturity. African Journal of Biotechnology, 2(2), 33-39.

Nyam, K. L., Tan, C. P., Lai, O. M., Long, K., \& Che Man, Y. B. (2009). Physicochemical properties and bioactive compounds of selected seed oil. LWT - Food Science and Technology, 42, 1396-1403.

Oesterling, E., Chopra, N., Gavalas, V., Arzuaga, X., Lim, E. J., Sultana, R., ... Hennig, B. (2008). Alumina nanoparticles induce expression of endothelial cell adhesion molecules. Toxicology Letters, 178(3), 160-166.

Ohkawa, H., Ohishi, N., \& Yagi, K. (1979). Assay for lipid peroxides in animal tissues by thiobarbituric acid reaction. Analytical Biochemistry, 95(2), 351-358.

Pandey, G., \& Jain, G. C. (2013). A review on toxic effects of aluminium exposure on male reproductive system and probable mechanisms of toxicity. International Journal of Toxicology and Applied Pharmacology, 3(3), 48-57.

Prabhakar, P. V., Reddy, U. A., Singh, S. P., Balasubramanyam, A., Rahman, M. F., Indu Kumari, S., ... Mahboob, M. (2012). Oxidative stress induced by aluminum oxide nanomaterials after acute oral treatment in Wistar rats. Journal of Applied Toxicology: JAT, 32(6), 436-445.

Qin, G., Tang, S., Li, S., Lu, H., Wang, Y., Zhao, P., ... Peng, L. (2017). Toxicological evaluation of silver nanoparticles and silver nitrate in rats following 28 days of repeated oral exposure. Environmental Toxicology, 32(2), 609-618.

Rastogi, A., Zivcak, M., Sytar, O., Kalaji, H. M., He, X., Mbarki, S., \& Brestic, M. (2017). Impact of metal and metal oxide nanoparticles on plant: A critical review. Frontiers in Chemistry, 5, 78. 
Ryan, E., Galvin, K., O'Connor, T. P., Maguire, A. R., \& O'Brien, N. M. (2007). Phytosterol, squalene, tocopherol content and fatty acid profile of selected seeds, grains, and legumes. Plant Foods for Human Nutrition (Dordrecht, Netherlands), 62(3), 85-91.

Salman, T. M., Olayaki, L. A., \& Oyeyemi, W. A. (2008). Aqueous extract of Telfairia occidentalis leaves reduces blood sugar and increases haematological and reproductive indices in male rats. African Journal of Biotechnology, 7(14), 2299-2303.

Sayed, F. (2014). The protective effect of pumpkin seed oil on azathioprine induced hepatic toxicity in adult male albino rats: Histological and immunohistochemical study. Basic Sciences of Medicine, 3(4), 85-100.

Serra, A., Letunic, I., Fortino, V., Handy, R. D., Fadeel, B., Tagliaferri, R., \& Greco, D. (2019). INSIdE NANO: A systems biology framework to contextualize the mechanism-of-action of engineered nanomaterials. Science Reports, 9, 179

Sharma, S., Sharma, R. K., Sharma, R., Sharma, A., Rai, A. K., Gupta, R. S., \& Singh, Y. (2003). Synthesis and characterisation of some new aluminium derivatives of Schiff bases containing $\mathrm{N}, \mathrm{O}$ and $\mathrm{S}$ donor atoms and the anti fertility activity of the derivative $\mathrm{Al}[\mathrm{S} \mathrm{C} 6 \mathrm{H} 4 \mathrm{~N}: \mathrm{C}(\mathrm{CH} 3) \mathrm{CH} 2 \mathrm{COCH} 3] 3$. Bioinorganic Chemistly and Applications, 215-225.

Shirai, T., Watanabe, H., Fuji, M., \& Takahashi, M. (2009). Structural properties and surfaces characteristics on aluminum oxide powders. Foundation Engineering Research Center Annual Report, 9, 23-31.

Shrivastava, R., Raza, S., Yadav, A., Kushwaha, P., \& Flora, S. J. (2014). Effects of subacute exposure to $\mathrm{TiO} 2, \mathrm{ZnO}$ and $\mathrm{Al} 2 \mathrm{O} 3$ nanoparticles on oxidative stress and histological changes in mouse liver and brain. Drug and Chemical Toxicology, 37(3), 336-347.

Sreelatha, S., Padma, P. R., \& Umadevi, M. (2009). Protective effects of Coriandrum sativum extracts on carbon tetrachloride-induced hepatotoxicity in rats. Food and Chemical Toxicology, 47(4), 702-708.

Stevenson, D. G., Eller, F. J., Wang, L., Jane, J. L., Wang, T., \& Inglett, G. E. (2007). Oil and tocopherol content and composition of pumpkin seed oil in 12 cultivars. Journal of Agricultural and Food Chemistry, 55(10), 4005-4013.

Tang, S., Wang, M., Germ, K. E., Du, H. M., Sun, W. J., Gao, W. M., \& Mayer, G. D. (2015). Health implications of engineered nanoparticles in infants and children. World Journal of Pediatrics, 11(3), 197-206.

Tarlani, A., Isari, M., Khazraei, A., \& Eslami Moghadam, M. (2017). New sol-gel derived aluminum oxide-ibuprofen nanocomposite as a controlled releasing medication. Nano Medicine Research Journal, 2(1), 28-35.

Tietz, N. W. (1995). Clinical guide to laboratory tests, (3rd ed., pp. 268-273). Philadelphia: WB. Saunders.

Vernet, P., Aitken, R. J., \& Drevet, J. R. (2004). Antioxidant strategies in the epididymis. Molecular and Cellular Endocrinology, 216(1-2), 31-39.

World Health Organization (1999). WHO laboratory manual for the examination of human semen and sperm-cervical mucus interaction, (4th ed., ). New York: Cambridge University Press

Yoshida, S., Hiyoshi, K., Ichinose, T., Takano, H., Oshio, S., Sugawara, I., ... Shibamoto, T. (2009). Effect of nanoparticles on the male reproductive system of mice. International Journal of Andrology, 32(4), 337-342.

Yousef, M. I., Kamel, K. I., El-Guendi, M. I., \& El-Demerdash, F. M. (2007). An in vitro study on reproductive toxicity of aluminium chloride on rabbit sperm: The protective role of some antioxidants. Toxicology, 239(3), 213-223.

Yousef, M. I., Mutar, T. F., \& Kamel, M. (2019). Hepato-renal toxicity of oral subchronic exposure to aluminum oxide and/or zinc oxide nanoparticles in rats. Toxicology Reports, 6, 336-346.

Yu, Q. Y., Fang, S. M., Zuo, W. D., Dai, F. Y., Zhang, Z., \& Lu, C. (2011). Effect of organophosphate phoxim exposure on certain oxidative stress biomarkers in the silkworm. Journal of Economic Entomology, 104(1), 101-106.

Zhang, Q. L., Li, M. Q., Ji, J. W., Gao, F. P., Bai, R., Chen, C. Y., ... Niu, Q. (2011). In vivo toxicity of nano-alumina on mice neurobehavioral profiles and the potential mechanisms. International Journal of Immunopathology and Pharmacology, 24(1 Suppl), 23S-29S.

Zhang, Y., Chen, W., Zhang, J., Liu, J., Chen, G., \& Pope, C. (2007). In vitro and in vivo toxicity of $\mathrm{CdTe}$ nanoparticles. Journal of Nanoscience and Nanotechnology, 7(2), 497-503.

Zhou, Q., Yue, Z., Li, Q., Zhou, R., \& Liu, L. (2019). Exposure to PbSe nanoparticles and male reproductive damage in a rat model. Environmental Science \& Technology, 53(22), 13408-13416.

\section{Publisher's Note}

Springer Nature remains neutral with regard to jurisdictional claims in published maps and institutional affiliations.

\section{Submit your manuscript to a SpringerOpen ${ }^{\circ}$ journal and benefit from:}

- Convenient online submission

- Rigorous peer review

- Open access: articles freely available online

- High visibility within the field

- Retaining the copyright to your article

Submit your next manuscript at $\boldsymbol{\nabla}$ springeropen.com 